\title{
GvHD Final Skin Score 0
}

National Cancer Institute

\section{Source}

National Cancer Institute. GVHD Final Skin Score O. NCI Thesaurus. Code C131026.

Body surface area involvement is 0 percent and there are no sclerotic features. 